\title{
CSF1R Gene Mutation
}

National Cancer Institute

\section{Source}

National Cancer Institute. CSF1R Gene Mutation. NCI Thesaurus. Code C133687.

A change in the nucleotide sequence of the CSF1R gene. 